\title{
MENYOAL INTERNET SEBAGAI RUANG PUBLIK DALAM PERSPEKTIF HABERMAS
}

\author{
Eben Haezer \\ Aliansi Jurnalis Independen \\ Email : ebent85@gmail.com
}

\begin{abstract}
The idea of the internet as an ideal public sphere has still become a debate. In some studies, some experts criticize the idea, but some accept it. This article discusses the problem as seen from the perspective of the theory of Public Sphere which was initiated by Jurgen Habermas It also briefly explains the thinking concept of Habermas, Virtual Public Sphere, Democracy in the Internet Age, and Visual Culture.
\end{abstract}

\section{Key Words: Public Sphere, Internet, Democracy}

\section{PENDAHULUAN}

Istilah ruang publik adalah istilah yang sangat longgar.Makna istilah ini sangat dipengaruhi oleh konteks dan ilmu yang sedang mengajinya. Dalam ilmu arsitektur dan tata kota misalnya, istilah ruang publik dimaknai secara teknis-arsitektural, dengan taman, mal, dan ruang terbuka lain sebagai contohnya. Maka untuk membedakan dengan istilah ruang publik dalam konsep Habermas, ruang publik dalam konteks ilmu arsitektur dan tata kota, sering disebut Public Space, bukan Public Sphere. Sementara dalam lingkungan siber, ruang publik dimaknai sebagai tempat dimana terjadinya interaksi maya. Selain itu, istilah ruang publik juga dimaknai berbeda dalam konteks yang lain, termasuk dalam konteks lingkungan media. (Prasetyo, 2012:171). Menurut Herry Priyono (2010: 372-374), ragam makna ruang publik dijelaskan dalam enam gugus pengertian. Di antaranya yaitu modal sosial (jaringan trust dan resiprositas), pelayanan publik, barang publik, budaya publik, tempat publik, dan interrelasi antara pasar, keluarga, pemerintah, dan kelompok independen yang membentuk sosialitas masyarakat.

Publik sendiri bukanlah konsep yang baru, melainkan terus mengalami perkembangan.Merujuk pada sejumlah literatur yang relevan, konsep publik bahkan sudah ditemukan sejak zaman Yunani kuno dan terus berkembang sampai saat ini. Menurut Arendt seperti yang dikutip oleh Wibowo (2010 : 23), pembedaan antara apa yang disebut dengan privat dengan apa yang disebut publik telah muncul sejak zaman 
Arkhaik di Athena, yaitu antara abad ke-8 SM hingga abad ke-6 SM, melalui istilah idiom (milik pribadi) dan koinon (milik bersama).

Bahkan pada abad ke-5 SM hingga abad ke-4 SM (zaman Klasik), konsep publik di Yunani kuno itu mengalami perkembangan signifikan karena mereka yang dapat berpartisipasi dalam membahas persoalan-persoalan publik bukan lagi sebatas pada warga negara (mereka yang lahir dari bapak asli Athena), tetapi juga orangorang lain yang tinggal di Athena meski bukan keturunan asli Athena.Sementara, merujuk pada Habermas (2007 : 66) yang mengamati publik dan ruang publik dari masyarakat borjuis di Perancis dan Inggris pada abad ke-18, yang disebut publik, idealnya memang bisa siapa saja yang terlibat dalam diskusi-diskusi mengenai politik dan persoalan-persoalan negara lainnya. Namun pada kenyataannya, ruang publik seperti salon dan kedai kopi hanya dapat diakses oleh kelompok- kelompok borjuis.

\section{PEMBAHASAN}

\section{Perkembangan Pemikiran Habermas}

Juergen Habermas (2007:41) mengatakan, ruang publik adalah ruang masyarakat privat (sphere of private people) yang berkumpul bersama menjadi sebuah publik. Namun definisi ini masih terbatas atau mengacu pada kelompok masyarakat borjuis yang memang mendominasi ruang-ruang publik seperti salon di Perancis, kedai kopi di Inggris, dan himpunan masyarakat meja (Tischgessellschaften) diJerman, dimasa-masa akhir abad ke-17 dan awal abad ke-18.

Kelompok masyarakat tersebut, mengklaim bahwa ruang publik ini diregulasi dari atas, demi untuk melawan otoritas publik. Dalam penelaahan ini, ruang publik yang merupakan bentukan dari masyarakat privat, dianggap memegang peran vital dalam upaya memperkuat demokrasi, yaitu sebagai ruang yang dihidupi oleh masyarakat dan berfungsi sebagai penghubung antara mereka dengan pemerintah. Melalui ruang publik, politik yang dijalankan secara formal, dikontrol lalu dipelajari melalui nalar publik.

Pandangan Habermas tentang ruang publik sebenarnya terdiri dari dua gelombang. Gelombang pertama dijelaskannya dalam buku The Structural Transformation of Public Sphere (1989), sementara gelombang kedua dijelaskan 
lewat buku Between Facts and Norms(1992).

Dalam buku pertama, ruang publik dilihat lewat lensa historis-sosiologis. Di buku itu, dijelaskan dua tema pokok, yakni asal mula ruang publik borjuis dan analisis terhadap perubahan struktural ruang publik di abad ke-18 hingga ke-19. Secara historis, ruang publik pertama kali muncul di Eropa pada abad ke-17 bersamaan dengan berkembangnya kapitalisme yang mendorong munculnyakelasbaru: Borjuis. Kelas ini muncul setelah mereka awalnya hanya melakukan kegiatan perdagangan biasa yang lalu berkembang menjadi produksi kapitalis. Dengan latar seperti ini, ruang publik yang muncul di era tersebut adalah ruang publik borjuis, yaitu ruang publik yang diisi oleh kelompok-kelompok aristokratis dan para intelektual borjuiskelompok terdidik yang memiliki kesamaan-kesamaan tertentu. (Prasetyo, 2012).

Ruang publik borjuis muncul ketika masyarakat sipil (kelompok borjuis) mulai melancarkan gugatan terhadap klaim kepublikan negara. Klaim kepubilkan negara itu direpresentasikan oleh negara dengan mengatur masyarakat. Maka kemudian muncullah forum-forum atau pertemuan-pertemuan yang di Perancis dan Inggris umumnya terjadi di kedai kopi dan salon, sementara di Jerman terjadi di Tischgesselschaften (himpunan masyarakat meja)—forum yang dihidupi oleh masyarakat terpelajar yang berakar dari Sprachgesselschaften (himpunan masyarakat sastra) lama di abadke-17.

Pertemuan-pertemuan tersebut selanjutnya membentuk basis institusional dari ruang publik borjuis.Dalam hubungannya dengan negara, ruang publik di masa itu merupakan jembatan antara kelas borjuis dengan negara.Melalui artikulasi opini yang mencuat dalam ruang publik, tersembunyi keinginan agar negara lebih responsif terhadap kebutuhan dan kepentingan kaum borjuis (Habermas, 1989 :14-26).

Di dalam buku pertama itu pula, Habermas menyebutkan tiga kriteria ruang publik.Kriteria tersebut disarikannya dari kecenderungan yang terjadi dalam ruang publik berupa kedai kopi, salon, dan tischgessellschaften.Kriteria-kriteria itu adalah, pertama, egaliter atau kesetaraan status.Dalam ruang publik, status cenderung dikesampingkan atau dengan kata lain, bentuk hubungan sosial yang tercipta, jauh dari mengangankan kesetaraan status. Kesetaraan atau persamaan status ini, 
penting karena menjadi landasan bagi pengukuhan argumen yang lebih baik dalam memenangkan perlawanan terhadap hierarki sosial.

Kedua, bebas dari dominasi.Dalam ruang publik yang terwujud di salon, kedai kopi, dan tischgesselschaften di Eropa pada abad ke-17 hingga ke-19, pembicaraan yang berlangsung menyangkut permasalahan-permasalahan yang masuk dalam wilayah “kepedulian umum”. Namun pembicaraan-pembicaraan tersebut berlangsung dengan mengesampingkan dominasi atau otoritas dari gereja dan negara yang dalam konteks saat itu memegang monopoli terhadap segala interpretasi, baik dalam filsafat, sastra, seni, ilmu pengetahuan, dan lainsebagainya.

Ketiga, inklusif.Dalam ruang publik, inklusivitas publik tercipta karena pada dasarnya setiap masalah yang diperbincangkan adalah persoalan-persoalan umum yang harus bisa dan mudah untuk diakses setiap orang. Dengan kata lain setiap orang harus sanggup berpartisipasi di dalamnya.

Dalam perkembangan selanjutnya, ruang publik tidak hanya temanifestasikan dalam ruang-ruang fisik seperti kedai kopi, salon, maupun tischgesselschaften, melainkan juga terwujud dalam media cetak. Dalam konteks masyarakat Eropa yang dikaji oleh Habermas pada saat itu, ruang publik dalam media cetak awalnya terwujud dalam jurnal-jurnal khusus kritik seni dan budaya yang melembagakan kritik sastra dari orang-orang atau pribadi-privat yang dianggap awam dalam hal seni dan sastra. Kritik-kritik seni (Kunstrichter) itu sendiri, meski diakui mengandung penilaian yang amatir, namun dapat dianggap sebagai perlawanan terhadap eksklusifnya seni dan sastra yang hanya dimonopoli kalangan bangsawan, keluarga kerajaan, borjuis, dan seniman. Jurnal-jurnal itulah yang kemudian menjadi dasar sehingga sampai kini, pers atau media massa, dianggap sebagai sebuah ruangpublik.

Sementara dalam buku keduanya-Between Facts and Norms-ruang Publik ditempatkan sebagai elemen dari bangunan teoritis yang lebih komprehensif tentang demokrasi deliberatif yang merupakan varian dari demokrasi yang fokus pada isu legitimasi politik. Model demokrasi deliberatif adalah arus balik dari demokrasi klasikortodoks yang memahami demokrasi semata dalam kerangka agregasi preferensi dan kepentingan warga negara melalui sarana konvensional seperti pemungutan suara dan lembaga perwakilan (Dryzek, 2000: v). Inti dari demokrasi ini adalah bahwa Volume 4, Nomor 2, Agustus 2018| 184 
sebuah keputusan akan terlegitimasi apabila telah mendapat persetujuan rasional lewat partisipasi di dalam pertimbangan mendalam (deliberation) yang otentik oleh semua pihak yang berkepentingan terhadap keputusan tersebut (Parkinson,2006:4). Pendekkata, oleh Habermas, melalui Factsand Norms, ruang publik disebut sebagai arena bagi setiap orang untuk berpartisipasi dalam upaya deliberasi.Karenanya di tahapan ini ruang publik tidak lagi dipandang secara konkret, historis, dan partikular sebagaimana dalam buku pertama, The Structural Transformation of Public Sphere.

\section{Ruang Publik Virtual}

Kehadiran internet harus diakui telah menyebabkan berkembangnya konsep mengenai ruang publik. Dengan adanya internet, interaksi-interaksi yang membahas mengenai permasalahan publik-yang awalnya hanya berlangsung di ruang-ruang fisik dan di dalam kolom-kolom media cetak_pada akhirnya berlangsung pula di dalam lingkungan virtual dengan menggunakan perantara komputer (Computer Mediated Communication atau (MC). Berdasarkan pemahaman itulah, maka Meyrowitz (1999:51) menyatakan bahwa penelitian komunikasi dalam konteks kekinian, seharusnya tidak lagi fokus pada pesan dan konten, tetapi juga kepada perkembangan teknologi yang sudah menjadi bagian tak terpisahkan dari masyarakat tersebut.

Hal yang sama juga disampaikan David Holmes (2005:2) bahwa saat ini, setiap saat individu selalu bersinggungan dengan teknologi informasi dan hidup dalam sebuah masyarakat informasi. Relasi antar individu pun tidak lagi terbatas pada relasi fisik, melainkan juga relasi interface yang diwakili oleh perangkat teknologi komunikasi. Bahkan, dalam perkembangan dunia siber saat ini, kehadiran individu sebagai obyek, tidak selalu menunjukkan wujud aslinya, namun bisa pula diwakili olehavatar atau gambar-gambar tertentu yang dikehendakinyasendiri.

Dalam perubahan yang sedemikian rupa, ruang publik tidak lagi hanya berlangsung dalam ruang-ruang fisik, namun juga dalam ruang-ruang virtual.Hal ini senada dengan pernyataan Papacharissi (2002:4) yang menyatakan bahwa media digital seperti internet, dengan infrastruktur yang menjajikan wacana tanpa batas serta aturan-aturan yang beroperasi di luar batas-batas geografis, akan mendorong 
terjadinya reinkarnasi virtual ranahpublik.

Ruang publik virtual sendiri, oleh sejumlah pakar dianggap sebagai ruang publik yang paling ideal dan lebih menjamin terciptanya demokratisasi.Anggapan ini muncul lantaran ruang-ruang publik modern yang telah ada sebelumnya, telah banyak terkooptasi oleh kepentingan-kepentingan ekonomi para pemilik modal. Bahkan menurut Habermas dalam Papacharissi (2002), ruang publik modern yang merujuk pada media massa arus utama, telah diusik oleh kekuatan komersialisasi dan dikompromosikan oleh konglomerasi sehingga menghasilkan wacana yang sebenarnya didominasi oleh kepentingan pemasangiklan.

Walau demikian, tidak selamanya ruang virtual (virtual space) bisa dianggap sebagai ruang publik (public sphere) virtual sebagaimana dimaksudkan oleh Habermas. Menurut Nasrullah (2012:38), hal ini karena internet bisa dikatakan hanya merupakan medium yang digunakan untuk diskusi atau debat politik, pertukaran ide atau gagasan, sampai membangun wacana sebagai jawaban atas realitas politik. Akan tetapi, fungsi ini sama juga dengan penggunaan internet sebagai sarana virtual semata.

Dengan demikian, pertanyaan yang muncul adalah bagaimana idealnya ruang publik virtual yang selaras dengan konsep ruang publik yang ditawarkan oleh Habermas? Menjawab pertanyaan itu, Papacharissi (2002:11) secara tegas menegaskan: "A virtual spaces enhances discussion. A virtual sphere enhances demcracy". Atau dengan kata lain, ruang virtual mendorong atau mewujudkan diskusi, sedangkan ruang publik virtual mewujudkan atau mendorong demokrasi.

Dalam kehidupan sehari-hari, perbedaan itu bisa terwujud dalam kebiasaan masyarakat pengguna situs jejaring sosial Facebook. Keberadaan wall atau dinding sebagai tempat pengguna menyampaikan ide dan gagasan, tidak bisa lantas dianggap sebagai upaya pengguna tersebut untuk menciptakan atau terlibat dalam debat kritis sebagaimana terjadi dalam ruang publik. Meski di "dinding” tersebut tersedia kolom tak terbatas untuk diisi dengan komentar dari pengguna lainnya, akan tetapi interaksi yang terjadi merupakan tanggapan biasa, seperti halnya terjadi ketika mereka berinteraksi dalam sebuah komunikasi tatap muka. Menurut Nasrullah, hal itulah yang disebut sebagai virtual space. Sementara virtual sphere, lebih relevan terwujud Volume 4, Nomor 2, Agustus 2018| 186 
melalui grup-grup diskusi maupun forum perbincangan politik sebagai respon atas realitas politik yangterjadi.

\section{Demokrasi di Era Internet}

Josiah Ober (2007 : 2) menyebutkan bahwa demokrasi berakar dari filsafat Yunani, di mana istilah ini mengandung dua kata yakni demos yang berarti rakyat dan kratos yang berarti kekuasaan. Dengan demikian, secara sederhana demokrasi dapat didefinisikan sebagai kekuasaan dari rakyat, oleh rakyat, dan untuk rakyat.

Sementara Samuel P Huntington (1991) menjelaskan adanya tiga gelombang besar demokrasi. Gelombang pertama adalah yang berlangsung pada kurun waktu 1828 hingga 1926 yang dimulai di Eropa dan dipicu oleh perkembangan di bidang sosial serta ekonomi. Sedangkan gelombang kedua, muncul karena faktor politik dan militer yang berlangsung selama kurun waktu 1943 hingga 1962.Pada periode ini, beberapa negara beralih ke demokrasi setelah Sekutu menang dalam Perang Dunia II. Sementara gelombang ketiga, menurut Huntington terjadi pada 1974 atau setelah Perang Dingin dan dipicu oleh beberapa sebab seperti melemahnya rezim otoriter, tekanan dari luar, serta perkembanganekonomi.

Kini, beberapa pakar percaya bahwa demokrasi di dunia ini telah memasuki gelombang keempat seiring dengan perkembangan teknologi digital dan diperkuat lagi dengan kebangkitan Dunia Arab atau Arab Springsejak 2010. Argumentasi ini, disebutkan oleh Howard dan Hussain (2014, 4), bahwa kehadiran internet, telepon seluler, dan berbagai aplikasi jejaring sosial telahmembawa perubahan politik di kawasan Afrika Utara serta Timur Tengah. Dengan mengontekstualisasikan dan melakukan periodisasi selama kurun waktu sepuluh tahun terhadap sistem media dan perkembangan infrastruktur informasi di Arab, maka dapat dipahami apa dampak dari hal tersebut, serta bagaimana dan mengapa hal ituterjadi.

Perubahan tatanan politik dan demokrasi akibat perkembangan internet ini selaras dengan pandangan Schmidt dan Cohen (2014 : xv) yang menyatakan bahwa dampak terbesar dari menjamurnya teknologi informasi adalah berpindahnya kekuasaan dari pemerintah dan lembaga ke tangan rakyat. Dengan adanya internet.Setiap orang maupun kelompok yang memiliki akses terhadap informasi dan 
saluran teknologi baru, dapat memiliki kesempatan untuk beropini, berpartisipasi, berkuasa, dan mengarahkan serta mempengaruhi terjadinya perubahan dalam masyarakat.

Perubahan wajah demokrasi yang dipengaruhi oleh internet rupanya juga berimbas terhadap industri media. Schmidt dan Cohen (2014 : 41) mengungkapkan pula bahwa kehadiran internet menjadikan media-media besar semakin kalah cepat dalam melaporkan berita-berita dari seluruh belahan dunia, sementara di saat yang bersamaan masyarakat juga kebanjiran informasi dari berbagai bentuk media sosial seperti Facebook, Twitter, Youtube, Blog, dan lain sebagainya. Hal ini pada akhirnya menyebabkan identitas masyarakat di masa depan akan sangat tergantung pada informasi dan sumber mana yang mereka percayai. Namun bagaimanapun itu, sisi positifnya adalah masyarakat di era internet memiliki alternatif yang beragam informasi. Menurut Amir Effendi Siregar (2014 : xxvii), banyaknya alternative terhadap pilihan informasi inilah yang disebut sebagai demokratisasi media. Dia mendefinisikan istilah tersebut sebagai sebuah peluang di mana semua pihak mendapat peluang seluas mungkin untuk terlibat dalam aktivitas-aktivitas media yang menjadi tempat dan jembatan bagi interaksi masyarakat demi menciptakan kehidupan berbangsa dan bernegara yang lebihbaik. 


\section{Kepentingan Publik Dalam Arena Ruang PublikVirtual}

Media massa dikenal sebagai pilar keempat dalam demokrasi yang menurut Coronel (2001), selain menjalankan fungsi sebagai anjing penjaga atau watchdog untuk mengawasi jalannya pemerintahan, juga menjalankan fungsi sebagai ruang untuk terjadinya diskusi dan perdebatan publik. Namun seiring waktu, fungsi ini banyak berkurang dan media lebih banyak mengumbar informasi-informasi sensasional.Terdegradasinya fungsi-fungsi media sebagai pilar keempat demokrasi tersebut disebabkan oleh berbagai macam hal. Mengenai hal tersebut, Coronel mengatakan demikian :

The reality, however, is that the media in new and restored democracy do not always live up to the ideal. They are hobbled by stringent laws, monopolistic ownership, and sometimes, the threat of brute force. State controls are not the only constraints. Serious reporting is difficult to sustain in competitive media markets that put a premium on the shallow and sensational. (Coronel, $2001: 1$ )

Pernyataan tersebut mengandung makna bahwa pada kenyataannya, media massa tidak selalu bisa menjalankan fungsinya yang ideal untuk mendorong demokrasi. Ini terjadi karena beberapa hal seperti peraturan hukum yang tidak member jaminan terhadap kebebasan pers, kepemilikan dan monopoli media, serta ancaman dari kekuatan-kekuatan massa yang luar biasa. Kontrol dari negara bukanlah satu-satunya kendala. Pasar media yang semakin kompetitif telah menyebabkan adanya upaya-upaya dari media untuk tetap bertahan, namun dengan cara menyebarkan hal-hal yang sensasional.

Dalam situasi-situasi yang demikian, semakin sulitlah bagi media massa untuk mampu menjalankan fungsi sebagai saluran kepentingan publik yang menurut Karman (2013) mencakup tindakan-tindakan untuk melakukan hal-hal yang penting, mendesak, dan berkaitan dengan prinsip-prinsip kehidupan masyarakat yang baik seperti keadilan, demokrasi, serta pelestarian nilai-nilai sosialbudaya.

Di tengah tidak optimalnya fungsi media massa sebagai ruang untuk mewadahi beragam kepentingan publik, kehadiran internet telah memberikan jalan yang baru yang lebih luas bagi demokrasi. Pepih Nugraha (2012) yang mengutip 
Kartajaya dan Hasanuddin (2010) menyatakan bahwa internet dan media sosial telah menyebabkan perubahan-baik positif maupun negatif-dalam kehidupan berdemokrasi.

Dengan adanya internet dan media sosial tersebut, masyarakat semakin aktif dalam beropini, menyampaikan kepentingan serta kebutuhan mereka, dan membahas kehidupan yang mereka jalani.Selain itu, mereka juga dengan mudah menyatakan pandangan terkait isu-isu aktual di sekitar mereka. Dengan kata lain, kehadiran internet dan media sosial ternyata bisa semakin meningkatkan partisipasi masyarakat terkait dengan isu- isu publik (Kartajaya, 2010). Terbuka lebarnya akses partisipasi masyarakat melalui internet menjadikan ruang publik semakin berkembang. Menurut Ubayasiri (2006), internet telah melahirkan sebuah ruang publik global dimana setiap orang memiliki akses langsung menuju forum-forum global di mana mereka dapat mengekspresikan argumentasi tanpa melalui mediasi, seleksi, dan penyensoran.

\section{BudayaVisual}

Masyarakat di era internet hidup dengan dikelilingi berbagai visual seperti televisi, fotografi, film, video, grafis, patung, poster, iklan, dan lain sebagainya. Gillian Rose (2001: 2) yang mengutip Hall (1997) mengatakan bahwa setiap citra visual yang diproduksi manusia, senantiasa mengandung makna-makna budaya. Sementara kebudayaan, sebagai sebuah proses dan praktik dalam kehidupan masyarakat, merupakan sesuatu yang dinamis sehingga pemaknaannya pun tergantung pada pengalaman dan pengetahuan masing-masing partisipan. Kondisi inilah yang kemudian menciptakan lahirnya term budaya visual atau visualculture.

Budaya visual (visual culture), menurut Ida (2011 : 84) merujuk pada kondisi di mana visual menjadi bagian dari kehidupan sosial. Budaya sosial, fokus pada bagaimana citra visual memvisualisasikan perbedaan sosial. Yang terpenting dari sebuah visual bukan lagi bagaimana visual itu tampak, melainkan bagaimana gambar itu dilihat oleh anggota masyarakat dengan cara yang tertentu (Rose, 2001).

Dalam menginterpretasikan sebuah citra atau visual, Rose (2001: 17-30) menyebutkan adanya tiga sudut pandang atau arena yaitu site of self, site of Volume 4, Nomor 2, Agustus 2018| 190 
production, dan site of audience. Dijelaskan oleh Ida (2011:86), site of self adalah di mana seorang peneliti ataupun mereka yang mengamati sebuah visual, bertindak sendiri dalam melakukan pemaknaan, interpretasi, dan pemahaman terhadapsebuahatau seperangkat obyek visual. Untuk menganalisis hal tersebut, terdapat beberapa metode yang bisa dipergunakan seperti analisis isi, analisis semiotik, analisis wacana, dan analisis tekstual lainnya. Sementara dalam site of production, cenderung berupaya untuk mengurai area produksi sebuah citra visual dengan mempertanyakan siapa yang membuat? Untuk siapa citra tersebut dibuat?Mengapa dan kapan dibuat? Serta peristiwa apa yang menjadi konteks dibuatnya citra tersebut.

Dalam penggunaan sudut pandang ini, dapat dipergunakan metode etnografi atau analisis wacana. Terakhir, dalam site of audience ada upaya untuk mencari tahu bagaimana masyarakat menginterpretasikan citra-citra visual yang diperhadapkan kepada mereka. Pada area ini, yang dipertanyakan adalah bagaimana khalayak menghubungkan citra-citra visual tadi dengan teks-teks lain yang ada di sekitar mereka.?Bagaimana profil khalayak tersebut?Serta mengapa mereka memaknainya demikian?Dalam area ini, metodologi yang dipergunakan adalah psikoanalisis, etnografi khalayak, dan analisis penerimaan atau receptionanalysis.

\section{KESIMPULAN}

Ide mengenai internet sebagai ruang publik yang ideal masih menjadi perdebatan sampai saat ini.Dalam beberapa penelitian, terdapat pakar-pakar yang mengkritik gagasan tersebut, namun sebagian pula menerima.Misalnya, dalam penelitian yang dilakukan oleh Jurgen Herhards dan Mike S Schafer (2009) yang berjudul "Is the Internet a Better Public Sphere? (Comparing old and new media in the US and Germany). Dalam penelitian, ini, Gerhard dan Schafer mempertanyakan apakah benar komunikasi yang terjadi di internet lebih baik ketimbang dari mediamedia tradisional, apabila ditinjau dari sudut pandang partisipasi publik.

Pertanyaan ini coba dijawab dengan membandingkan bagaimana partisipasi publik berlangsung dalam membahas sebuah wacana yang sama, yang disajikan di 
sejumlah media cetak dan media online terkemuka di Amerika Serikat dan Jerman. Partisipasi publik itu diukur dengan menggunakan data dari 1.900 artikel di media cetak selama kurun waktu 1999 hingga 2001. Data-data dari artikel tersebut kemudian dibandingkan dengan konten-konten dengan topik serupa yang disajikan di 144 website atau mediaonline.

Pembandingan ini dilakukan untuk menilai sejauh mana tingkat inklusivitas dan dominasi berlangsung dalam dua jenis media tersebut.Setelah penelitian, Gerhard dan Schafer menyimpulkan bahwa bukti-bukti yang mendukung pandangan bahwa internet adalah ruang publik yang ideal sangatlah minim. Hal ini terjadi karena dalam konten-konten yang mereka teliti di media-media online, dominasi masih tetap terjadi dan dilakukan oleh aktor-aktor yang memiliki pemahaman luas mengenai topik yang sedang diangkat. Dominiasi ini sama halnya terjadi di media cetak karena jurnalis ternyata lebih banyak memberi ruang bagi aktor-aktor tersebut ketimbang untuk pembaca yang meski memiliki kepentingan, namun dianggap tidakkompeten.

Satu hal yang penting untuk dikritik dalam penelitian tersebut adalah media online yang dibandingkan dengan media cetak bukanlah media-media yang memberi ruang untuk konten-konten buatan pengguna atau user generated content. Media online yang dibandingkan adalah media-media yang dikelola oleh korporasi sehingga pada dasarnya akan tetap ada dominasi dari pengelola media yang salah satunya diwujudkan melalui content framing. Padahal, idealnya sebuah ruang publik mesti memberi ruang kepada publik secara luas atau dengan kata lain, terbuka untuk segala opini dan gagasan. Selain itu, karena tidak memberi ruang pada user generated contentyang merupakan representasi dari gagasan-gagasan individu sebagai anggota publik, maka prinsip inklusivitas yang juga merupakan salah satu syarat idealnya ruang publik, tidak pula bisatercapai.

Sedangkan penelitian lain adalah penelitian oleh Fulya Sen (2012) yang berjudul The Social Media As A Public Sphere: The Rise Of Social Opposition.Dalam penelitian ini, Sen menyatakan bahwa ruang publik ideal adalah sebuah model yang tidak pernah benar-benar bisa terwujud, khususnya dalam media sosial. Kesimpulan ini dicapai setelah dia meneliti kekuatan media sosial dalam menciptakan ruang publik. 
Penelitian ini dilakukan Sen dengan bertolak dari pandangan umum yang menyatakan bahwa internet adalah ruang publik deliberatif ${ }^{1}$ yang ideal untuk mewujudkan partisipasi masyarakat dalam politik. Asumsi lainnya, internet yang disebutnya sebagai media baru, telah menjanjikan adanya forum-forum baru untuk pengembangan kelompok-kelompok minat atau interest groups yang kemudian akan melahirkan opini-opini publik, serta membuka peluang untuk terjadinya dialog antara politisi dan masyarakat yang aktif, sehingga akan menyediakan arena baru bagi wacana-wacana publik dan opini publik (McQuail,2005:150-151).

Dalam penelitiannya ini, Sen tidak menggunakan banyak alat analisis yang rumit dan tidak membidik platform media sosial tertentu sebagai obyek yang dikaji. Yang dilakukannya adalah mengaji literatur dan melakukan debat teoritis terhadap model ruang publik versi Jurgen Habermas, lalu membandingkannya dengan isu-isu di media sosial seputar Arab Spring yang terjadi di Mesir dan Tunisia pada awal 2011. Dengan cara yang demikian, maka muncul sebuah generalisasi bahwa semua media sosial tidak dapat menjadi ruang publik yang ideal. Padahal, semestinya generalisasi semacam itu harus dihindari. Sebab tidak menutup kemungkinan beberapa ruangruang di media sosial tertentu, tanpa disadari telah menjadisebuahruang publik yang ideal karena inklusivitas dan kesetaraan yang tercipta di dalamnya serta belum adanya dominasi, termasuk dominasi yang muncul karena kepentingan modal.

Demi menghindari generalisasi yang demikian, maka perlulah dilakukan penelitian yang fokus pada media tertentu yang masih benar-benar baru dan belum terkooptasi oleh kepentingan-kepentingan modal.Hal ini dilakukan dengan asumsi bahwa ketiadaan kepentingan modal yang masuk di media tersebut, masih memungkinkan untuk terciptanya sebuah ruang publik virtual yang ideal.

Selanjutnya, penelitian yang dilakukan oleh Nishat Kasi (2011) yang berjudul Public Sphere and Dynamics of the Internet.Dalam penelitian ini, Kazi menganggap bahwa internet masih memiliki potensi untuk menjadi ruang publik deliberatif yang ideal. Namun potensi ini hanya bisa terwujud apabila didukung oleh kondisi tertentu yakni adanya kemauan dari aktor-aktor penggerak untuk menciptakan sendiri sebuah ruang publik virtual universal yang dapat menjamin terwujudnya demokrasi 
deliberatif dan meningkatkan keterlihatan atau visibility dari ruang publik yangsejati.

Kesimpulan tersebut dimunculkan Kazi karena melihat bahwa media cetak yang mula-mula dianggap sebagai ruang publik ideal, lambat laun terdistorsi fungsinya karena adanya kepentingan modal di dalamnya. Kepentingan-kepentingan modal ini terwujud dalam beberapa hal seperti semakin tergerusnya ruang-ruang dalam media yang sebenarnya sudah terbatas, demi untuk memenuhikepentinganpara pemasang iklan. Saat kemudian iklan tidak terbatas dibuat untuk korporasi, melainkan juga dibuat untuk kepentingan-kepentingan politik, maka semakin lama muncullah ketergantungan media tersebut terhadap para pemasang iklan tadi.Ketika ketergantungan ini terjadi, di situlah titik di mana media tidak lagi menjadi ruang publik deliberatif yang ideal.Dalam membuat kesimpulan tersebut, penelitian yang dilakukan oleh Kazi tidak berangkat pada sebuah proses penelitian yang dilakukan dengan menyoroti produk-produk new media tertentu.

\section{REFERENSI}

Berger, Peter L \& Luckmann, Thomas. The Social Construction of Reality : A Treatise in the Sociology of Knowledge ( $6^{\text {th }}$ edition). England: Penguin Books, 1991.

Bly, Robert. The Sibling Society. New York: Vintage, 1997.

Coronel, Sheila S. The Role of the Media in Deepening Democracy.2001.

Creswell, J.W. Research Design: Qualitative and QuantitativeApproaches.

London: Sage Publications Ltd, 1995.

Dryzek, John S. Deliberative Democracy and Beyond: Liberals, Critics, Contestations. New York: Oxford University Press, 2000

Gerhards, Jurgen \& Schafer, Mike S.Is the internet a better public sphere? Comparing old and new media in the US and Germany. Journal of New Media and Society XX (X) pp.1-18. Sage Publications Ltd, 2009.

Gunawan, Imam. Metode Penelitian Kualitatif: Teori dan Praktik (Cetakan Ketiga). Jakarta: Bumi Aksara, 2015.

Habermas, Jurgen. The Structural Transformation of The Public Sphere: An Inquiry into a Category of Bourgeois Society (Translated by Thomas Burger with the Assistance of Frederick Lawrence). Cambridge, Massachusetts: The MIT Press, 2001.

Habermas, Jurgen. Between Facts and Norms: Contributions to a Discourse Theory of Law and Democracy. United States of America: MIT Press, 1992.

Volume 4, Nomor 2, Agustus 2018| 194 
Hadi, Ido Prijana. Penelitian Khalayak Dalam Perspektif Reception Analysis.

Jurnal Ilmiah Scriptura Vol.3 No.1 pp 1-7, 2009.

Hall, Stuart. Representation : Cultural Representations and SignifyingPractices. London: Sage Publications Ltd and TheOpen University, 1997.

Holmes, David. Communication Theory: Media, Technology and Society. Sage Publications Ltd, 2005.

Howard, PhillipN \&Hussain, Muzzamil M. Democracy's Forth Wave?Digital Media and The Arab Spring. Oxford: Oxford University Press, 2014

Huntington, Samuel P. Democracy's Third Wave. Journal of DemocracyVol.2

No.2. pp.12-34, 1991

Ida, Rachmah.Metode Penelitian: Kajian Media dan Budaya. Surabaya: Airlangga

University Press, 2011

Karman.Media dan Kepentingan Publik: Praktik Media Massa Menurut Teori Normatif. Jurnal Insani Nomor 15 pp. 21-27, 2013

Kazi, Public Sphere and Dynamics of the Internet.An Interdisciplinary Journal Vol.5/2011.

Maia, Rousiley C.M. Deliberative Democracy and Public Sphere Typology.

Estudos Em Comunicacao no.1 pp.69-102, 2007.

McQuail, Denis. McQuail's Mass Communications Therory $6^{\text {th }}$ Edition. New Delhi: Sage Publications India Pvt Ltd, 2005.

Meyrowitz, J.Understandings of media. ETC: A Review of General Semantics, 56(1), 4452, 1999.

Miller, Daniel. How the World Changed Social Media. London : UCL Press, 2016. Nasrullah, Internet dan Ruang Publik Virtual: Sebuah Refleksi atas Teori.

Jurnal Komunikator Vol.4 No.1 pp.26-35, 2012

Neumann, Elisabeth Noelle. The Theory of Public Opinion : The Concept of the Spiral of Silence. In Communcation Yearbook 14, James A. Anderson (ed). Newbury Park, Carolina: Sage Publication Ltd, 1991.

Nugraha, Pepih. Citizen Journalism: Pandangan, Pemahaman, dan Pengalaman. Jakarta: Penerbit BukuKompas, 2012.

Ober J, Raaflaub K.A, Wallace, R. Origins of Democracy in ancient Greece.

California: University of California Press, 2007.

Papacharissi, Zizi. The virtual sphere, The internet as a public sphere.

Journal of New Media \& Society, Vol.4 no.1 pp. 9-27, 2002

Prasetyo, Antonius Galih. Menuju Demokrasi Rasional: Melacak Pemikiran Jurgen Habermas Tentang Ruang Publik. Jurnal Ilmu Sosial dan Ilmu Politik Vol.16 No.2 
pp.169-184, 2012

Priyono, Herry.Menyelamatkan Ruang Publik_dalam buku Ruang Publik: Melacak Partisipasi Demokratis dari Polis Sampai Cyberspace, pp.369-399. Yogyakarta: Kanisius, 2010

Rose, Gillian. Visual Methodologies: An Introduction to the Interpretation of Visual Materials. London: Sage Publications Ltd, 2001.

Schmidt, Eric \& Cohen, Jared.The New Digital Age :Cakrawala Baru Negara, Bisnis, dan Hidup Kita. Jakarta : Kepustakaan Populer Gramedia, 2014

Sen, Fulya. The Social Media As A Public Sphere: The Rise Of Social

Siregar, Amir Effendi. Mengawal Demokratisasi Media: Menolak Konsentrasi, Membangun Kebragaman. Jakarta: Penerbit Buku Kompas, 2014

Sobur, Alex. Analisis Teks Media: Suatu Pengantar Untuk ANalisis Wacana, Analisis Semiotik, Analisis Framing. Bandung: Rosdyakarya, 2001

Supelli, Karlina. Ruang Publik Dunia Maya.dalam Ruang Publik : Melacak Partisipasi Demokratis dari Polis Sampai Cyberspace, pp.329-346. Yogyakarta : Kanisius, 2010

Tapscott, Don. Grown Up Digital: How The Net Generation is Changing Your World. USA: The McGraw-Hill, 2009.

Ubayasiri, Kasun. Internet and The Public Sphere: A Glimpse of YouTube.

eJournalist Vol 6. No. 2, 2006.

Van Dijk, Teun.Principles of Critical Discourse Analysis.Jurnal Discourse \& Society Vol 4(2),pp.249-283. London : SAGE, 1993

VanDijk,Teun.18CriticalDiscourseAnalysis:TheHandbookofDiscourseAnalysis. Pp 349-371. Blackwell PublisherLtd, 2001

VanDijk,Teun.IdeologyandDiscourse:AMultidisciplinaryIntroduction. Barcelona : Pompeu FabraUniversity, 2013

Van Eymeren, Margawati. Media Komunikasi dan Dampaknya terhadap Kebudayaan:Analisis Atas Pandangan Herbert Marshall McLuhan. Jakarta: Pusat Kajian Filsafat dan Pancasila, 2014

West, Richard \& Turner, Lynn H. Pengantar Teori Komunikasi: Analisis dan Aplikasi (Buku 2) (Edisi 3). Jakarta: Salemba Humanika, 2008

Wibowo, A.Setyo. Kepublikan dan Keprivatan di Dalam Polis Yunani Kuno, dalam Ruang Publik : Melacak Partisipasi Demokratis dari Polis Sampai Cyberspace, pp.23-61. Yogyakarta: Kanisius, 2010

Yasir. Paradigma Komunikasi Kritis: Suatu Alternatif Bagi Ilmu Komunikasi.

Jurnal Ilmu Komunikasi Vol.1 No.1 pp 1-55, 2012

Volume 4, Nomor 2, Agustus 2018| 196 